This work was supported by the U.S. Department of Energy, National Nuclear Security Administration, Nevada Operations Office.

An Affirmative Action/Equal Opportunity Employer

This report was prepared as an account of work sponsored by an agency of the United States Government. Neither the Regents of the University of California, the United States Government nor any agency thereof, nor any of their employees make any warranty, express or implied, or assume any legal liability or responsibility for the accuracy, completeness, or usefulness of any information, apparatus, product, or process disclosed, or represent that its use would not infringe privately owned rights. Reference herein to any specific commercial product, process, or service by trade name, trademark, manufacturer, or otherwise does not necessarily constitute or imply its endorsement, recommendation, or favoring by the Regents of the University of California, the United States Government, or any agency thereof. The views and opinions of authors expressed herein do not necessarily state or reflect those of the Regents of the University of California, the United States Government, or any agency thereof. Los Alamos National Laboratory strongly supports academic freedom and a researcher's right to publish; as an institution, however, the Laboratory does not endorse the viewpoint of a publication or guarantee its technical correctness. 
Laboratory and Field Studies Related to Radionuclide Migration at the

Nevada Test Site in Support of the

Underground Test Area and

Hydrologic Resources Management Projects

David L. Finnegan

Joseph L. Thompson 



\section{CONTENTS}

EXECUTIVE SUMMARY ......................................................................... vii

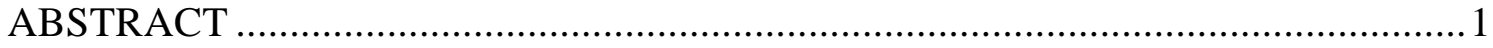

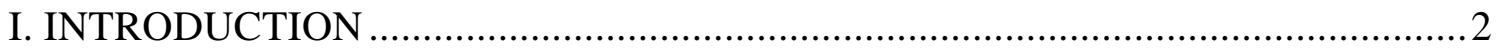

II. RADIOCHEMICAL ANALYSES.................................................................

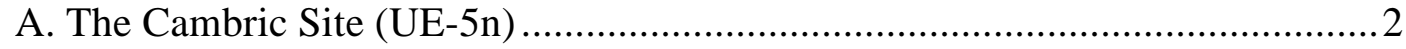

B. The Nash Site (UE-2ce) .......................................................................

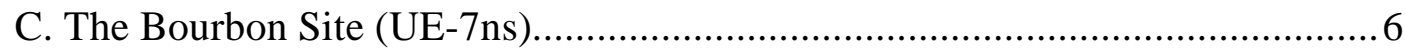

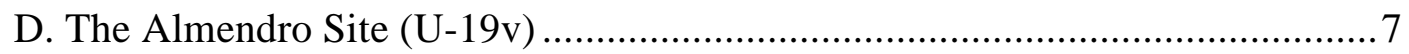

E. Area 5 Characterization Sites (ER5-3, ER5-3\#2, ER5-4) .............................. 9

F. Measurements of ${ }^{237} \mathrm{~Np}$ for Hot Well Samples ......................................... 13

III. GROUNDWATER CHARACTERIZATION .................................................. 15

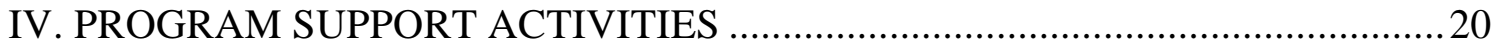

A. Document Reviews/Meetings ..................................................... 20

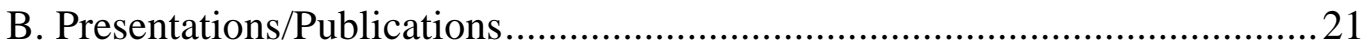

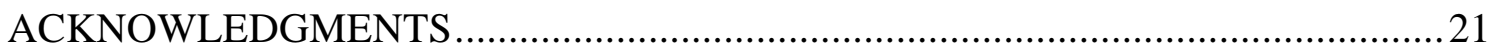

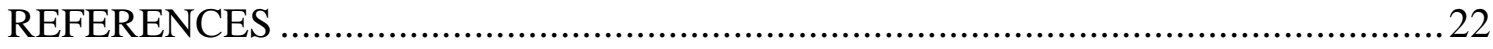




\section{EXECUTIVE SUMMARY}

This report describes work done by Chemistry Division personnel at Los Alamos National Laboratory (LANL) during FY 2001 for the U. S. Department of Energy National Nuclear Security Administration Nevada Operations Office (NNSA/NV). Ours is part of a multiagency program supported by the Defense Programs and Environmental Restoration divisions of NNSA/NV which are strongly affected by the extent of radioactive contamination of the underground environment of the Nevada Test Site (NTS) because this influences the use of land and water resources there. We are attempting to develop a descriptive model that accounts for the present distribution of radionuclides and predicts future movement within or outside NTS boundaries. The LANL Chemistry Division contribution to this effort during the past year consisted of measurements of radionuclide concentrations in water samples collected from cavities or chimneys of nuclear test locations on the NTS. Because we have been sampling some of these locations for many years, we are able to identify trends in the data that give us insights into how radionuclides may become part of the hydrologic source term, that is, how they become mobile with groundwater. As a complement to this work, we used our downhole probe to measure in situ water temperature, $\mathrm{pH}$, specific conductance, dissolved oxygen, and oxidation-reduction potential. These parameters influence the speciation of radionuclides dissolved in groundwater and affect how they may interact with their geologic environment.

We added more information to our database for the Cambric site where we have conducted studies since 1975 . We again detected tritium in the auxiliary hole UE-5n, probably from diffusion of effluent water during the time RNM-2S was continually pumped. This year levels were slightly higher than in 1999, indicating continued diffusion of tritium from the surface to the UE-5n water. After a very small amount of ${ }^{137} \mathrm{Cs}$ was unexpectedly found in the one $210 \mathrm{~L}$ barrel sample from UE-5n in 1999, two $210 \mathrm{~L}$ barrel samples from 2001 were analyzed for ${ }^{137} \mathrm{Cs}$. No ${ }^{137} \mathrm{Cs}$ was detected in either sample, indicating that the ${ }^{137} \mathrm{Cs}$ detected in the 1999 sample was from field or laboratory contamination.

During FY 2001 we collected bailed water samples from satellite wells at the Nash site (UE-3ce) and Bourbon site (UE-7ns). These satellite wells were drilled and pumped in the late 1970's and early 1980's to look for the movement of radionuclides from these two tests, which were detonated just above the water table, into the carbonate aquifer below. Radioactivity was found in the water from both wells, and the activity was followed for several years. However, the pumps failed, and the wells have not been pumped since 1984. Bailed samples were last collected in 1993. The data from the samples collected this year are similar to those collected in 1993. However, the reason for collecting the bailed samples this year was to measure the radioactivity in the well before a new pump is installed, thus enabling us to look at changes of radioactivity in the water after pumping. 
For the last four years we have collected water samples from the Almendro site (U-19v) because the water that filled the cavity has remained at a very high temperature at this location. We have a unique opportunity to see the effects of elevated temperature on the solubility and speciation of residues from a nuclear test. Thus far we have not been able to sample at the very bottom of the cavity, but we do seem to see variations with depth of both tritium and ${ }^{85} \mathrm{Kr}$ concentrations.

We collected samples from 3 characterization wells in Frenchman Flat: ER5-3, ER5-3\#2 and ER5-4. The waters from each well were analyzed for their radionuclide content $\left({ }^{3} \mathrm{H},{ }^{85} \mathrm{Kr}\right.$ and gamma rays). No radioactivity (other than natural $\mathrm{U}$ and $\mathrm{Th}$ daughters and ${ }^{40} \mathrm{~K}$ ) was expected in the wells, but the analyses were performed to provide baseline data for the wells. It turned out that a small amount of ${ }^{3} \mathrm{H}$ activity was found during the drilling of the ER5-4 well. The activity occurred at a depth roughly corresponding to the depth of the Cambric test (U-5n), and since ER5-4 is only several hundred meters from Cambric, it was likely the source of the ${ }^{3} \mathrm{H}$.

Water samples from eight wells that contain significant amounts of radioactivity were analyzed for ${ }^{237} \mathrm{~Np}$. The radionuclide ${ }^{237} \mathrm{~Np}$, which has a long half-life, is thought to be mobile in water. An ultra-sensitive ICP/MS with a detection limit of $15 \mathrm{ppq}$ for ${ }^{237} \mathrm{~Np}$ was used to do the analyses. Very small amounts of ${ }^{237} \mathrm{~Np}$, ranging from $<15$ to $210 \mathrm{ppq}$, were found in the samples.

We were able to make in situ water measurements again this year with our Hydrolab Minisonde 4a multiprobe. We were able to measure temperature, specific conductivity, dissolved oxygen, $\mathrm{pH}$, and oxidation-reduction potential in eight wells at the NTS. These data are needed by the modeling group to better define the water chemistry and its effect on transport in groundwater at the NTS. This second collection of data has enabled us to prepare procedures and learn lessons that will lead to more consistent and quantitative data collection in the future 


\title{
LABORATORY AND FIELD STUDIES RELATED TO RADIONUCLIDE MIGRATION AT THE NEVADA TEST SITE IN SUPPORT OF THE UNDERGROUND TEST AREA PROJECT AND HYDROLOGIC RESOURCES MANAGEMENT PROJECT
}

OCTOBER 1, 2000-SEPTEMBER 30, 2001

by

\author{
David L. Finnegan and Joseph L. Thompson
}

\begin{abstract}
This report details the work of Chemistry Division personnel from Los Alamos National Laboratory in FY 2001 for the U. S. Department of Energy National Nuclear Security Administration Nevada Operations Office (NNSA/NV) under its Defense Programs and Environmental Restoration divisions. Los Alamos is one of a number of agencies collaborating in an effort to describe the present and future movement of radionuclides in the underground environment of the Nevada Test Site. This fiscal year we collected and analyzed water samples from a number of expended test locations at the Nevada Test Site. We give the results of these analyses and summarize the information gained over the quarter century that we have been studying several of these sites. We find that by far most of the radioactive residues from a nuclear test are contained in the melt glass in the cavity. Those radionuclides that are mobile in water can be transported if the groundwater is moving due to hydraulic or thermal gradients. The extent to which they move is a function of their chemical speciation, with neutral or anionic materials traveling freely relative to cationic materials that tend to sorb on rock surfaces. However, radionuclides sorbed on colloids may be transported if the colloids are moving. Local conditions strongly influence the distribution and movement of radionuclides, and we continue to study sites such as Almendro, which is thermally quite hot, and Nash and Bourbon, where radionuclides had not been measured for 8 years. We collected samples from three characterization wells in Frenchman Flat to obtain baseline radiochemistry data for each well, and we analyzed eight wells containing radioactivity for ${ }^{237} \mathrm{~Np}$, using our highly sensitive ICP/MS. We have again used our field probe that allows us to measure important groundwater properties in situ. We conclude our report by noting document reviews and publications produced in support of this program.
\end{abstract}




\section{INTRODUCTION}

In this report we describe the work done in the Chemistry Division (C-Division) at Los Alamos National Laboratory (LANL) for the Hydrologic Resources Management Program (HRMP) and the Underground Test Area (UGTA) projects. These are projects of the U. S. Department of Energy National Nuclear Security Administration Nevada Operations Office (NNSA/NV) conducted in the divisions of Defense Programs and Environmental Restoration. Our work supports the Defense Programs' concern for responsible stewardship of land and water resources at the Nevada Test Site (NTS) and assists the NNSA/NV Environmental Restoration Division in assessing the radionuclide contamination resulting from nuclear weapons testing at the NTS. We collaborate with other technical organizations, including Lawrence Livermore National Laboratory (LLNL), the Desert Research Institute (DRI), the U. S. Geological Survey (USGS), and the U. S. Environmental Protection Agency (EPA), and with contractors such as Bechtel Nevada (BN) and International Technology (IT).

Since 1973 LANL personnel have been participating in the study of the effects of nuclear testing on the environment at the NTS. We are particularly concerned with learning how radioactive residues from these tests may move underground in groundwater aquifers. An analysis of where radioactive nuclides are after being deposited some 10 to 40 years ago may enable us to evaluate the suitability of portions of the NTS for future use in testing or for possible release for other uses. We need to know what fraction of the radioactive material associated with a nuclear test is still contained in the cavity region in melt glass (the radiologic source term) and what fraction has dissolved or formed colloids that can be transported with moving groundwater (the hydrologic source term). We also need to know the direction and velocity of groundwater flow at local test sites and through the region. Additionally, we need an understanding of the speciation and reactions (for example, sorption) of mobile radioactive materials. Using this type of information, we are constructing models that describe the present and future extent of radioactive contamination of groundwater at the NTS. The work described in this report was done to learn more about the radiological and hydrological source terms at selected nuclear test sites. It provides the raw data from which models may be constructed and allows a check of model predictions with present realities.

This report is for work done in FY 2001. It is the latest in a series of annual reports ${ }^{1-24}$ topical reports, ${ }^{25-31}$ and journal articles. ${ }^{32-43}$

\section{RADIOCHEMICAL ANALYSES}

\section{A. The Cambric Site - UE-5n}

The Cambric test was conducted in the alluvium of Frenchman Flat in 1965 at a depth of $294 \mathrm{~m}$, some $70 \mathrm{~m}$ below the water table. Ten years later the RNM-1 hole was drilled into and through the cavity, and numerous rock and water samples were

collected. ${ }^{25} \mathrm{We}$ found that nearly all of the radioactive material associated with the test 
was still in the cavity region. A satellite hole (RNM-2S) was drilled $91 \mathrm{~m}$ from the cavity, and pumping began in order to observe groundwater transport of radionuclides. We have periodically sampled water from both the RNM-1 and RNM-2S holes since $1975 .^{28}$ Continuous pumping at RNM-2S was terminated in 1991 after approximately $1.7 \mathrm{E} 7 \mathrm{~m}^{3}$ of water had been discharged.

UE-5n, an exploratory hole, was drilled to a depth of $514 \mathrm{~m}$ in March 1976 and completed with a $27 \mathrm{~cm}$ casing to a depth of $464 \mathrm{~m}$. It is approximately $560 \mathrm{~m}$ east and south of the RNM-1 hole. In September 1999 we participated with DRI and LLNL in sampling water withdrawn with a Bennett pump from approximately $3 \mathrm{~m}$ below the water level in the casing. ${ }^{24} \mathrm{We}$ found a trace amount of ${ }^{137} \mathrm{Cs}$ in the water from this hole and were quite surprised because of our experience at RNM-2S, where we were unable to move ${ }^{137} \mathrm{Cs} 91 \mathrm{~m}$ from the Cambric test in the course of 16 years of pumping groundwater. ${ }^{27}$ We recounted our samples and eliminated the possibility of contamination in the counter. However, because of unique sampling conditions and the very small quantity detected, there was a chance for contamination of the sample at the time of collection as well as the possibility during the analytical process. Because only one drum sample was collected, additional sampling was deemed necessary to determine the validity of the detected ${ }^{137} \mathrm{Cs}$.

Water samples were again collected at UE-5n in April 2001 to help clear up the issue of the ${ }^{137} \mathrm{Cs}$ in the water. Representatives from IT, DRI, LLNL and LANL collected samples of the water being pumped from the well. Well sampling and water chemistry data are contained in Table I. LANL collected two 55-gal. drums, three $2.2 \mathrm{~L}$ pressure tubes and two grab samples. These samples were analyzed for ${ }^{3} \mathrm{H},{ }^{85} \mathrm{Kr},{ }^{237} \mathrm{~Np}$ and gamma activity, and the resulting data are in Table II.

In 2001 the water at UE-5n was pumped from the well using the DRI Bennett pump, and the pumping rate was very low $(1.3 \mathrm{~L} / \mathrm{min})$. With this flow rate it took at least 160 minutes to fill the 55-gal. drum and more when other samples were collected at the same time from a side port. The length of time to fill the drum increased the possibility of wind-blown contamination getting into the water sample, especially when the wind was gusty. To minimize the possibility of wind-blown contamination getting inside the drum while it was being filled, tape was placed around the bungholes (this was not done in 1999). The drum samples were dried and counted for gamma activity. The only activity found in the two 55-gal. drum samples during the gamma analyses was background gamma activity. The activity consisted of ${ }^{238} \mathrm{U},{ }^{235} \mathrm{U},{ }^{232} \mathrm{Th}$ and their daughters and ${ }^{40} \mathrm{~K}$. No ${ }^{137} \mathrm{Cs}$ was found in either sample. These results lead to the conclusion that the drum sample collected in 1999 was contaminated in the field or in the laboratory and that no ${ }^{137} \mathrm{Cs}$ is present in the water at this well.

Tritium found in UE-5n samples in the April 2001 collection had an average activity of 5.0E3 Bq/L. Tritium in the September 1999 samples averaged 5.2E3 Bq/L. If the tritium values for the April 2001 samples are decay corrected to the time of collection for the November 1999 samples, the tritium activity has an average of 5.5E3 Bq/L, a slight increase in activity over the period of time between sampling. 
The source of the tritium at UE-5n is not entirely clear. The unlined ditch down which the effluent from RNM-2S ran from 1975 to 1991 passes within approximately $100 \mathrm{~m}$ of UE-5n. The hole itself is almost equidistant between the Cambric test (U-5e) and Diluted Waters test (U-5b), both approximately $560 \mathrm{~m}$ away. At the Cambric site there is apparently very little water movement at the cavity depth (approximately $300 \mathrm{~m}$ ) because the radionuclides residual to the test in 1965 were still present when the cavity was re-entered in 1974. If such low water movement were also true at the Diluted Waters site, then it would seem that the activity at UE-5n would most likely come from lateral diffusion from the ditch. The tritium activity in ditch water peaked at approximately 2.6E5 Bq/L (corrected to Cambric $\mathrm{t}_{0}=05 / 14 / 1965$ ) in 1980, and declined to $4.9 \mathrm{E} 4 \mathrm{~Bq} / \mathrm{L}$ when pumping was stopped in 1991. Present levels of tritium activity at RNM-2S are approximately the same as when pumping was stopped (that is, $5.5 \mathrm{E} 4 \mathrm{~Bq} / \mathrm{L}$ corrected to $\mathrm{t}_{0}$ or $7.6 \mathrm{E} 3 \mathrm{~Bq} / \mathrm{L}$ at present time). The current tritium content at UE-5n is about $30 \%$ below that at RNM-2S.

It will be interesting to track concentration changes at UE-5n in future years, particularly to see if it continues to rise and exceeds current concentrations at RNM-2S, thus suggesting diffusion of higher concentration tritium from the ditch. Such data would enable us to determine lateral diffusion rates through the alluvium of Frenchman Flat—rates essential for modeling this corrective action unit.

As was the case in our 1999 sample, ${ }^{24}$ no ${ }^{85} \mathrm{Kr}$ was detected in the water from UE-5n. This is a strong indication that the water in UE-5n is from the RNM-2S ditch since this dissolved gas would be lost from the water while it was flowing along the ditch.

Grab samples revealed ${ }^{237} \mathrm{~Np}$ at very low levels $\left(82-84 \mathrm{ppq} ; \mathrm{ppq}=10^{-15}\right)$. These numbers have fairly large errors associated with them, but they do indicate that ${ }^{237} \mathrm{~Np}$ is present in the water at UE-5n. Although ${ }^{237} \mathrm{~Np}$ was not routinely measured in RNM-2S water samples, analyses performed this year on the samples collected at RNM-1 and RNM-2s in 2000 gave very similar ${ }^{237} \mathrm{~Np}$ results as those for UE-5n. The ${ }^{237} \mathrm{~Np}$ data for Cambric will be investigated more fully next year.

Table I. UE-5n Well Sampling and Water Information

\begin{tabular}{|l|l|}
\hline Volume pumped & 4730 Liters \\
\hline Pump Rate & $1.3 \mathrm{~L} / \mathrm{min}$ \\
\hline Water Temp & $19.9^{\circ} \mathrm{C}$ \\
\hline Electrical Conductivity & $407 \mu$ siemans/cm \\
\hline $\mathrm{pH}$ & 8.9 \\
\hline Dissolved Oxygen & $4.4 \mathrm{mg} / \mathrm{L}\left(@ 23.0^{\circ} \mathrm{C}\right.$ \\
\hline Turbidity & $1.98 \mathrm{NTU}$ \\
\hline Perforations & $219-223 \mathrm{~m}$ \\
\hline SWL & $214 \mathrm{~m}$ \\
\hline
\end{tabular}


Table II. UE-5n Sample Information and Data

(Activities are corrected $\mathrm{t}_{0}$ collection time, 04/19/2001)

\begin{tabular}{|c|c|c|c|c|c|c|c|}
\hline $\begin{array}{c}\text { LANL } \\
\text { Sample \# }\end{array}$ & $\begin{array}{c}\text { Collection } \\
\text { Date }\end{array}$ & $\begin{array}{c}\text { Sample } \\
\text { Type }\end{array}$ & $\begin{array}{c}{ }^{3} \mathrm{H} \\
(\mathrm{Bq} / \mathrm{L})\end{array}$ & $\begin{array}{c}{ }^{3} \mathrm{H}_{\text {adj }}{ }^{*} \\
(\mathrm{~Bq} / \mathrm{L})\end{array}$ & $\begin{array}{c}{ }^{85} \mathrm{Kr} \\
(\mathrm{Bq} / \mathrm{L})\end{array}$ & $\begin{array}{c}{ }^{237} \mathrm{~Np} \\
(\mathrm{ppq})\end{array}$ & Gammas \\
\hline \hline $4343-01-110$ & $04 / 19 / 2001$ & $\begin{array}{c}55-\text { gal. } \\
\text { drum }\end{array}$ & $5.04 \mathrm{E} 3$ & $5.52 \mathrm{E} 3$ & na & na & $\begin{array}{c}\text { Nat. K, U, Th } \\
\text { and daughters }\end{array}$ \\
\hline $4343-01-140$ & $04 / 19 / 2001$ & $\begin{array}{c}55-\text { gal. } \\
\text { drum }\end{array}$ & $5.04 \mathrm{E} 3$ & $5.52 \mathrm{E} 3$ & na & na & $\begin{array}{c}\text { Nat. } \mathrm{K}, \mathrm{U}, \mathrm{Th} \\
\text { and daughters }\end{array}$ \\
\hline $4343-01-210$ & $04 / 19 / 2001$ & $\begin{array}{c}\text { Pressure } \\
\text { tube }\end{array}$ & $5.07 \mathrm{E} 3$ & $5.55 \mathrm{E} 3$ & $<4 \mathrm{E}-2$ & na & na \\
\hline $4343-01-220$ & $04 / 19 / 2001$ & $\begin{array}{c}\text { Pressure } \\
\text { tube }\end{array}$ & $5.04 \mathrm{E} 3$ & $5.52 \mathrm{E} 3$ & $<4 \mathrm{E}-2$ & na & na \\
\hline $4343-01-230$ & $04 / 19 / 2001$ & $\begin{array}{c}\text { Pressure } \\
\text { tube }\end{array}$ & $4.96 \mathrm{E} 3$ & $5.43 \mathrm{E} 3$ & $<4 \mathrm{E}-2$ & na & na \\
\hline $4343-01-120$ & $04 / 19 / 2001$ & $\begin{array}{c}\text { Grab } \\
\text { Sample }\end{array}$ & $5.11 \mathrm{E} 3$ & $5.60 \mathrm{E} 3$ & na & 82 & na \\
\hline $4343-01-130$ & $04 / 19 / 2001$ & $\begin{array}{c}\text { Grab } \\
\text { Sample }\end{array}$ & $4.93 \mathrm{E} 3$ & $5.40 \mathrm{E} 3$ & na & 84 & na \\
\hline
\end{tabular}

$*={ }^{3} \mathrm{H}$ is decay corrected to Sept. 1999 for comparison with previously collected samples

na $=$ not analyzed

ppq $=$ parts per quadrillion

\section{B. The Nash Site (UE-2ce)}

UE-2ce is a satellite well drilled 183 m south of the Nash test, which was conducted in January 1967 at a depth of $364 \mathrm{~m}$. The satellite well, drilled in 1977, extends to a depth of about $500 \mathrm{~m}$ and was completed to draw from the bottom $75 \mathrm{~m}$. The water level at this site was $428 \mathrm{~m}$ in 1977 and $448 \mathrm{~m}$ in 1985. Pumping began in the summer of 1977, and tritium analyses were done on a weekly basis. The tritium concentrations rose exponentially with the cumulative volume of water pumped from the well. By late 1977 a few thousand cubic meters of water had been pumped and the tritium concentration had begun to level off at around $4 \mathrm{E} 5 \mathrm{~Bq} / \mathrm{L}$ (calculated to $\mathrm{t}_{0}=01 / 19 / 1967$ ). Pumping continued intermittently until 1984, when the tritium concentrations measured by Los Alamos personnel were in the range $1.4-2.8 \mathrm{E} 6 \mathrm{~Bq} / \mathrm{L}\left(\right.$ at $\left.\mathrm{t}_{0}\right)$, and some $3.7 \mathrm{E} 4 \mathrm{~m}^{3}$ had been withdrawn. The pump failed in 1984 and was removed in 1989. In 1993 we collected a 2-L grab sample in a pressure tube and measured $2 \mathrm{E} 4 \mathrm{~Bq} / \mathrm{L}$ tritium (calculated to $\mathrm{t}_{0}$ ). It is apparent that with pumping we collected water containing tritium associated with the Nash test. It is not clear whether the cavity from this test actually extended to the water table or whether the tritium was ejected into fractures which reached the water table. Numerous analyses were done for other radionuclides produced by the test. Only a few radionuclides were found in measurable concentrations; these included ${ }^{22} \mathrm{Na},{ }^{85} \mathrm{Kr}$ and (possibly) ${ }^{90} \mathrm{Sr}$. Thus, only nuclides mobile in groundwater and 
produced in relatively high concentrations were collected from the satellite well. The ratio of ${ }^{85} \mathrm{Kr}$ to ${ }^{3} \mathrm{H}$ (approximately E-3) was significantly lower than the ratio produced by the test, as has been the case at other sites. Details of analytical work on UE-2ce samples are contained in references $1-3,6-8,17$, and 44 .

UE-2ce is an important site because it is the only case in which it is clear that radionuclides from a nuclear test at the Nevada Test Site are in water in the Paleozoic (carbonate) aquifer. When a new pump is installed in UE-2ce, we will be able to better determine how tritium concentrations have changed since 1984 and whether other radionuclides are detectable in water in this important aquifer. The baseline data from grab samples collected this year are difficult to correlate precisely with previous data because the well has been stagnant for many years. Our values, shown in Table III, indicate that the tritium concentrations in the well bore are similar to those measured previously when the well was not being pumped and lower than when it was being pumped.

Table III. Analysis of Water Collected from UE-2ce

\begin{tabular}{|c|c|c|c|c|}
\hline Sample ID & $\begin{array}{c}\text { Collection } \\
\text { Date }\end{array}$ & $\begin{array}{l}\text { Sample } \\
\text { Depth }\end{array}$ & $\begin{array}{l}{ }^{3} \mathrm{H}(\mathrm{Bq} / \mathrm{L}) \\
@ \mathrm{ct}^{*} @ \mathrm{t}_{0} *\end{array}$ & $\begin{array}{l}{ }^{85} \mathrm{Kr}(\mathrm{Bq} / \mathrm{L}) \\
@ \mathrm{ct}^{*} @ \mathrm{t}_{0} *\end{array}$ \\
\hline 5081-01-211 & $008 / 22 / 2001$ & $457 \mathrm{~m}$ & 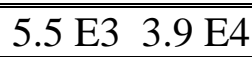 & $3.0 \mathrm{E} 12.9 \mathrm{E} 2$ \\
\hline $5081-01-221$ & $08 / 22 / 2001$ & $457 \mathrm{~m}$ & $5.5 \mathrm{E} 3 \quad 3.9 \mathrm{E} 4$ & $3.0 \mathrm{E} 1 \quad 2.8 \mathrm{E} 2$ \\
\hline 5081-01-231 & $08 / 22 / 2001$ & $457 \mathrm{~m}$ & $5.5 \mathrm{E} 3 \quad 3.9 \mathrm{E} 4$ & $3.9 \mathrm{E} 13.7 \mathrm{E} 2$ \\
\hline
\end{tabular}

$* c t=$ count time $($ Oct 2001$) ; \mathrm{t}_{0}=01 / 19 / 1967$

\section{The Bourbon Site (UE-7ns)}

UE-7ns is a satellite well drilled $172 \mathrm{~m}$ southeast of the Bourbon test, which was conducted in January 1967 at a depth of about 560 m. In 1976 the satellite well was drilled to $672 \mathrm{~m}$ and cased so as to draw from the final $62 \mathrm{~m}$. The water level at this site is about $600 \mathrm{~m}$ and is approximately $100 \mathrm{~m}$ below the tuff-Paleozoic contact. Since the cavity formed by the Bourbon test was in the Paleozoic formation and close to (but above) the Paleozoic (carbonate) aquifer, the satellite well may provide a means to measure any radionuclide contamination of the aquifer. However, the satellite well does not produce a large flow of water, and sampling has been sporadic. Samples taken from 1978 to 1982 had tritium concentrations in the range of E1 to E2 Bq/L. ${ }^{44}$ In 1983 a solar powered pump was installed, and some 200-L samples were collected. Tritium concentrations measured in 1984 by LLNL and LANL were in the range of 5 E1 to $1 \mathrm{E} 2 \mathrm{~Bq} / \mathrm{L}$. In 1989 the pump was removed from UE-7ns. A 2-L grab sample was collected at a depth of $617 \mathrm{~m}$ by LANL in $1993,{ }^{17}$ and the tritium concentration was less than $3.7 \mathrm{E} 1 \mathrm{~Bq} / \mathrm{L}$. A new pump is scheduled to go into UE-7ns, so several 2-L grab samples were collected this year and analyzed for tritium and ${ }^{85} \mathrm{Kr}$. Personnel from LANL, LLNL and the USGS did the sampling as a collaborative effort. 
Table IV. Analysis of Water Collected from UE-7ns

\begin{tabular}{|c|c|c|c|c|}
\hline Sample ID & Collection & Sample & ${ }^{3} \mathrm{H}(\mathrm{Bq} / \mathrm{L})$ & ${ }^{85} \mathrm{Kr}(\mathrm{Bq} / \mathrm{L})$ \\
\hline & Date & Depth & $@ \mathrm{ct}^{*} @ \mathrm{t}_{0} *$ & $@ \mathrm{ct}^{*} @ \mathrm{t}_{0} *$ \\
\hline 5090-01-210 & $08 / 21 / 01$ & $617 \mathrm{~m}$ & $\sim \mathrm{E} 1 \sim \mathrm{E} 2$ & $2.7 \mathrm{E} 12.6 \mathrm{E} 2$ \\
\hline $5090-01-220$ & $08 / 21 / 01$ & $617 \mathrm{~m}$ & 4.8 E1 3.4 E2 & $1.6 \mathrm{E} 1 \quad 1.5 \mathrm{E} 2$ \\
\hline $5090-01-230$ & $08 / 21 / 01$ & $617 \mathrm{~m}$ & $1.2 \mathrm{E} 28.6 \mathrm{E} 2$ & $6.3 \mathrm{E} 1 \quad 5.9 \mathrm{E} 2$ \\
\hline
\end{tabular}

$* \mathrm{ct}=$ count time $($ Oct 2001$) ; \mathrm{t}_{0}=01 / 20 / 1967$

The water samples collected this year are similar in tritium content to those analyzed since 1978; that is, they contain tritium at near background levels (and approximately at the limits of what can be measured without tritium enrichment procedures). There does seem to be an interesting trend in the tritium data, suggesting that repeated immersion of the pressure tubes may have mixed the water in the bore hole and resulted in detection of underlying higher tritium concentrations. With this limited sample set, such a hypothesis cannot be confirmed. Presumably, future pumping should resolve the issue.

The ${ }^{85} \mathrm{Kr}$ values do not correspond with our experience at other locations on the NTS, where the ${ }^{85} \mathrm{Kr} /{ }^{3} \mathrm{H}$ ratio is about E-3 or E-4. Similarly, the 1993 pressure tube sample analyzed by Los Alamos gave a ${ }^{85} \mathrm{Kr}$ concentration of about 1.4 E1 Bq/L, far higher than would have been expected. Again, pumping of this well is indicated to allow us to collect samples representative of the groundwater. It has been over thirty years since the Bourbon event, so this is an appropriate time to again assess possible migration of radionuclides in the carbonate aquifer from the Bourbon test.

\section{The Almendro Site (U-19v)}

The Almendro site is unique among those we have studied at the NTS in that it has remained thermally hot for many years. The test was conducted in 1973; the bottom of the cavity is approximately $1.16 \mathrm{E} 3 \mathrm{~m}$ vertical. In 1996 the temperature at $1.09 \mathrm{E} 3 \mathrm{~m}$ was still $157^{\circ} \mathrm{C}$. This elevated temperature has prevented sample collection until recent years, and we still have not been able to sample from the bottom of the cavity. In Table V we show representative values of tritium and ${ }^{85} \mathrm{Kr}$ collected in pressure tubes during recent sampling campaigns. Because it takes several months to analyze the krypton activity, the final results for the samples collected in September 2000 were not finished until FY 2001 and therefore are reported for the first time in this year's report.

LLNL and LANL, using the USGS wireline truck, collected bailed samples in May 2001. There were problems with the sampling tool during the collection of the pressure tube samples. The sampling tool has a valve that opens at depth to allow water into the pressure tubes. The valve closes before the pressure tubes are brought to the surface. During collection of the first pressure tube, there was no indication at the surface 
that the valve on the tube opened when the 'open' switch was pressed. When the samples were brought to the surface, it appeared that the pressure tube was about half full, so the sample was kept. The second sample was collected without incident. However, for the third pressure tube, the sampling tool did not work at all, and no water was collected in the pressure tube. Therefore, sampling was discontinued.

When the first pressure tube was prepared for analysis, there was only about $140 \mathrm{ml}$ of water in the $2.2 \mathrm{~L}$ tube. There was not enough water to complete the ${ }^{85} \mathrm{Kr}$ analysis. Therefore, for the three pressure tubes, only one ${ }^{85} \mathrm{Kr}$ analysis was completed successfully. However, ${ }^{3} \mathrm{H}$ analysis was successfully performed on the first two samples.

These samples showed ${ }^{3} \mathrm{H}$ activity at levels similar to those detected in previous years (see Table V). However, ${ }^{85} \mathrm{Kr}$ activities were down by about a factor of 10 . The only explanation we have is that the sampling tool did not completely close and most of the $\mathrm{Kr}$ was lost from the sample.

Table V. Tritium and ${ }^{85} \mathrm{Kr}$ in Water Samples From Almendro (All activities are corrected to the Almendro $\mathrm{t}_{0}=06 / 06 / 1973$.)

\begin{tabular}{|c|c|c|c|c|}
\hline Sample ID & Sample Date & $\begin{array}{c}\text { Sample Depth } \\
\text { Vertical }(\mathrm{m}) *\end{array}$ & ${ }^{3} \mathrm{H}(\mathrm{Bq} / \mathrm{L})$ & ${ }^{85} \mathrm{Kr}(\mathrm{Bq} / \mathrm{L})$ \\
\hline \hline $7910-98-210$ & $09 / 22 / 98$ & $1.02 \mathrm{E} 3$ & $2.9 \mathrm{E} 7$ & $1.0 \mathrm{E} 4$ \\
\hline $7910-99-220$ & $08 / 17 / 99$ & $9.14 \mathrm{E} 2$ & $2.1 \mathrm{E} 7$ & $4 \mathrm{E} 3$ \\
\hline $7910-99-230$ & $08 / 18 / 99$ & $9.14 \mathrm{E} 2$ & $2.3 \mathrm{E} 7$ & $1 \mathrm{E} 3$ \\
\hline $7910-00-210$ & $09 / 26 / 00$ & $9.42 \mathrm{E} 2$ & $2.7 \mathrm{E} 7$ & LIA \\
\hline $7910-00-220$ & $09 / 27 / 00$ & $9.42 \mathrm{E} 2$ & $2.6 \mathrm{E} 7$ & $4 \mathrm{E} 3$ \\
\hline $7910-00-230$ & $09 / 27 / 00$ & $9.42 \mathrm{E} 2$ & $2.7 \mathrm{E} 7$ & $1 \mathrm{E} 4$ \\
\hline $7910-00-240$ & $09 / 27 / 00$ & $9.42 \mathrm{E} 2$ & $2.4 \mathrm{E} 7$ & $4 \mathrm{E} 3$ \\
\hline $7910-01-210$ & $05 / 30 / 01$ & $9.42 \mathrm{E} 2$ & $2.6 \mathrm{E} 7$ & na \\
\hline $7910-01-220$ & $05 / 31 / 01$ & $9.42 \mathrm{E} 2$ & $2.4 \mathrm{E} 7$ & $5 \mathrm{E} 2$ \\
\hline
\end{tabular}

*This assumes slant depth $\mathrm{x} 0.936=$ vertical depth. na $=$ not analyzed; LIA $=$ Lost in Analysis

Almendro is a particularly interesting site because of its high temperature. We might expect that this would result in larger-than-normal concentrations of fission products in solution. However, our analyses of water samples collected in 1996 revealed measurable quantities of ${ }^{137} \mathrm{Cs}$ only, with perhaps a trace of ${ }^{60} \mathrm{Co}$. Also, the ratio of ${ }^{3} \mathrm{H}$ to ${ }^{85} \mathrm{Kr}$ is not especially high (say, relative to that in Cheshire), as would occur if the krypton gas was expelled because of low solubility at high temperature. We are currently pursuing equipment that will allow us to sample at the high temperatures present at the bottom of this hole. 


\section{E. Area 5 Characterization Sites (ER5-3, ER5-3\#2, ER5-4)}

\section{$\underline{\text { ER5-3 }}$}

Well ER5-3 is located in northern Frenchman Flat and was drilled and completed during FY 2000. There are 2 completion zones, with the upper completion zone 441-543 $\mathrm{m}$ in Quaternary-Tertiary colluvium (part of the alluvial aquifer) and the lower completion zone 723-794 m below ground surface in Rainier Mesa Tuff (a welded-tuff aquifer). Sampling was performed to acquire chemical data that represent the composite chemistry of all water-producing intervals. The stressed flow logging performed at this well indicated that over 97 percent of the produced water originated from the lower completion zone. ${ }^{45}$

Samples were collected at ER5-3 on March 28, 2001. Representatives from IT, LLNL and LANL collected samples of the water being pumped from the well. Well sampling and water chemistry data are contained in Table VI. LANL collected two 55-gal. drums, three 2.2 L pressure tubes and two grab samples. These samples were analyzed for ${ }^{3} \mathrm{H},{ }^{85} \mathrm{Kr},{ }^{237} \mathrm{~Np}$ and gamma activity as indicated in Table VII.

No activity was found in these samples except background gamma activity in the 55-gal. drum samples. The activity consisted of ${ }^{238} \mathrm{U},{ }^{235} \mathrm{U},{ }^{232} \mathrm{Th}$ and their daughters and ${ }^{40} \mathrm{~K}$.

Table VI. ER5-3 Well Sampling and Water Information

\begin{tabular}{|l|l|}
\hline Volume pumped & $11,958,230 \mathrm{~L}$ \\
\hline Pump Rate & $570 \mathrm{~L} / \mathrm{min}$ \\
\hline Water Temp & $30.0^{\circ} \mathrm{C}$ \\
\hline Electrical Conductivity & $445 \mu$ siemans/cm \\
\hline $\mathrm{pH}$ & 8.3 \\
\hline Dissolved Oxygen & $6.4 \mathrm{mg} / \mathrm{L}$ \\
\hline Turbidity & $0.63 \mathrm{NTU}$ \\
\hline Perforations & $\begin{array}{l}441-543 \mathrm{~m} \text { and } \\
723 \text { and } 794 \mathrm{~m}\end{array}$ \\
\hline SWL & $283 \mathrm{~m}$ \\
\hline
\end{tabular}


Table VII. ER5-3 Sample Information and Data

(corrected to count time, 06/15/2001)

\begin{tabular}{|l|c|c|c|c|c|c|}
\hline LANL Sample \# & $\begin{array}{c}\text { Collection } \\
\text { Date }\end{array}$ & $\begin{array}{c}\text { Sample } \\
\text { Type }\end{array}$ & $\begin{array}{c}{ }^{3} \mathrm{H} \\
(\mathrm{Bq} / \mathrm{L})\end{array}$ & $\begin{array}{c}{ }^{85} \mathrm{Kr} \\
(\mathrm{Bq} / \mathrm{L})\end{array}$ & $\begin{array}{c}{ }^{237} \mathrm{~Np} \\
(\mathrm{ppq})\end{array}$ & Gammas \\
\hline $4530-01-110$ & $03 / 28 / 2001$ & $\begin{array}{c}55 \text {-gal. } \\
\text { drum }\end{array}$ & $<30$ & na & na & $\begin{array}{c}\text { Nat. K, U, Th and } \\
\text { daughters }\end{array}$ \\
\hline $4530-01-120$ & $03 / 28 / 2001$ & $\begin{array}{c}55 \text {-gal. } \\
\text { drum }\end{array}$ & $<30$ & na & na & $\begin{array}{c}\text { Nat. K, U, Th and } \\
\text { daughters }\end{array}$ \\
\hline $4530-01-210$ & $03 / 28 / 2001$ & $\begin{array}{c}\text { Pressure } \\
\text { tube }\end{array}$ & $<30$ & $<4 \mathrm{E}-2$ & na & na \\
\hline $4530-01-220$ & $03 / 28 / 2001$ & $\begin{array}{c}\text { Pressure } \\
\text { tube }\end{array}$ & $<30$ & $<4 \mathrm{E}-2$ & na & na \\
\hline $4530-01-230$ & $03 / 28 / 2001$ & $\begin{array}{c}\text { Pressure } \\
\text { tube }\end{array}$ & $<30$ & $<4 \mathrm{E}-2$ & na & na \\
\hline $4530-01-130$ & $03 / 28 / 2001$ & $\begin{array}{c}2 \text {-L Grab } \\
\text { Sample }\end{array}$ & $<30$ & na & $<20$ & na \\
\hline $4530-01-140$ & $03 / 28 / 2001$ & $\begin{array}{c}\text { 2-L Grab } \\
\text { Sample }\end{array}$ & $<30$ & na & $<20$ & \\
\hline
\end{tabular}

na $=$ not analyzed

\section{ER5-3\#2}

Well ER-5-3\#2, also located in northern Frenchman Flat about 30 meters east of ER5-3, was drilled and completed in FY 2000 and recompleted in March 2001. It has a single completion zone in the lower carbonate aquifer (below the local Quaternary and Tertiary units) $1424-1732 \mathrm{~m}^{45}$

Samples from the completion zone were collected at the end of the production phase of the constant-rate test conducted at the well. Samples were collected at ER5-3\#2 on 5/17/2001 by representatives from IT, LLNL and LANL. Well sampling and water chemistry data are contained in Table VIII. LANL collected two 55-gal drums, three 2.2 L pressure tubes and two grab samples. These samples were analyzed for ${ }^{3} \mathrm{H},{ }^{85} \mathrm{Kr}$, ${ }^{237} \mathrm{~Np}$ and gamma activity, as indicated in Table IX.

No activity was found in these samples except background gamma activity in the 55-gal. drum samples. The activity consisted of ${ }^{238} \mathrm{U},{ }^{235} \mathrm{U},{ }^{232} \mathrm{Th}$ and their daughters and ${ }^{40} \mathrm{~K}$. 
Table VIII. ER5-3\#2 Well Sampling and Water Information (from IT)

\begin{tabular}{|l|l|}
\hline Volume pumped & $13,096,000 \mathrm{~L}$ \\
\hline Pump Rate & $136 \mathrm{~L} / \mathrm{min}$ \\
\hline Water Temp & $33.8^{\circ} \mathrm{C}$ \\
\hline Electrical Conductivity & $1158 \mu$ siemans/cm \\
\hline $\mathrm{pH}$ & 6.7 \\
\hline Dissolved Oxygen & $1.8 \mathrm{mg} / \mathrm{L}$ \\
\hline Turbidity & $0.59 \mathrm{NTU}$ \\
\hline Perforations & 1424 to $1732 \mathrm{~m}$ \\
\hline SWL & $293 \mathrm{~m}$ \\
\hline
\end{tabular}

Table IX. ER5-3\#2 Sample Information and Data

(corrected to count time, 08/17/2001)

\begin{tabular}{|c|c|c|c|c|c|c|}
\hline LANL Sample \# & $\begin{array}{l}\text { Collection } \\
\text { Date }\end{array}$ & $\begin{array}{l}\text { Sample } \\
\text { Type }\end{array}$ & $\begin{array}{c}{ }^{3} \mathrm{H} \\
(\mathrm{Bq} / \mathrm{L})\end{array}$ & $\begin{array}{c}{ }^{85} \mathrm{Kr} \\
(\mathrm{Bq} / \mathrm{L})\end{array}$ & $\begin{array}{r}{ }^{237} \mathrm{~Np} \\
(\mathrm{ppq})\end{array}$ & Gammas \\
\hline $4532-01-110$ & $05 / 17 / 2001$ & $\begin{array}{l}\text { 55-gal. } \\
\text { drum }\end{array}$ & $<30$ & na & na & $\begin{array}{l}\text { Nat. K, U, Th } \\
\text { and daughters }\end{array}$ \\
\hline $4532-01-120$ & $05 / 17 / 2001$ & $\begin{array}{l}\text { 55-gal. } \\
\text { drum }\end{array}$ & $<30$ & na & na & $\begin{array}{l}\text { Nat. K, U, Th } \\
\text { and daughters }\end{array}$ \\
\hline $4532-01-210$ & $05 / 17 / 2001$ & $\begin{array}{c}\text { Pressure } \\
\text { tube }\end{array}$ & $<30$ & $<4 \mathrm{E}-2$ & na & na \\
\hline $4532-01-220$ & $05 / 17 / 2001$ & $\begin{array}{c}\text { Pressure } \\
\text { tube }\end{array}$ & $<30$ & $<4 \mathrm{E}-2$ & na & na \\
\hline $4532-01-230$ & $05 / 17 / 2001$ & $\begin{array}{c}\text { Pressure } \\
\text { tube }\end{array}$ & $<30$ & $<4 \mathrm{E}-2$ & na & na \\
\hline $4532-01-130$ & $05 / 17 / 2001$ & $\begin{array}{l}\text { 1-L Grab } \\
\text { Sample }\end{array}$ & $<30$ & na & $<20$ & na \\
\hline $4532-01-140$ & $05 / 17 / 2001$ & $\begin{array}{c}\text { 0.5-L Grab } \\
\text { Sample }\end{array}$ & $<30$ & na & $<20$ & na \\
\hline
\end{tabular}

na $=$ not analyzed

\section{ER5-4}

The drilling of ER5-4 began in January 2001. During the drilling in February 2001, IT personnel found ${ }^{3} \mathrm{H}$ in the water from the well at a depth of approximately $305 \mathrm{~m}$. When this happened, IT collected three $4 \mathrm{~L}$ water samples for LANL. These samples were collected on 02/15/2001 and shipped to Los Alamos on 03/27/2001.

All three samples were analyzed for ${ }^{3} \mathrm{H}$ (in duplicate), and the results are reported in Table X. Two of the samples were dried and then combined to increase the possibility of detecting gamma activity and were analyzed using gamma spectroscopy. The only 
activities found in the samples were natural uranium and thorium isotopes and their daughters and ${ }^{40} \mathrm{~K}$. These isotopes are naturally in the water and surrounding material, or they may possibly have been from the drilling materials put into the hole.

No fission products or other weapon-related radionuclides other than ${ }^{3} \mathrm{H}$ were found in the samples.

Because no weapon-related activity was detected in the combination of samples 110 and 120, sample 130 was not analyzed for gamma activity.

While the detection of ${ }^{3} \mathrm{H}$ in the water was a surprise, it was not completely unexpected. The ${ }^{3} \mathrm{H}$ was found at a depth equivalent to the depth of the Cambric test, and the well is only several hundred meters from Cambric ground zero.

Table X. ER-5-4 Sample Information

\begin{tabular}{|c|c|c|c|c|c|c|}
\hline $\begin{array}{c}\text { LANL } \\
\text { Sample \# }\end{array}$ & IT Sample \# & IT Lot \# & $\begin{array}{c}\text { IT Serial } \\
\#\end{array}$ & $\begin{array}{c}\text { Collection } \\
\text { Date }\end{array}$ & $\begin{array}{c}{ }^{3} \mathrm{H} \\
(\mathrm{Bq} / \mathrm{L})\end{array}$ & Gammas \\
\hline \hline 4540-01-110 & ER5-4-02151-1 & M-0208020 & 675423 & $02 / 15 / 2001$ & $\begin{array}{c}170 \\
160\end{array}$ & $\begin{array}{c}\text { Nat. K, U, Th } \\
\text { and daughters }\end{array}$ \\
\hline 4540-01-120 & ER5-4-02151-1 & M-0208020 & 675427 & $02 / 15 / 2001$ & $\begin{array}{c}200 \\
200\end{array}$ & $\begin{array}{c}\text { Nat. K, U, Th } \\
\text { and daughters }\end{array}$ \\
\hline 4540-01-130 & ER5-4-02151-1 & M-0208020 & 675428 & $02 / 15 / 2001$ & 200 & \\
& & & & & 180 & \\
\hline
\end{tabular}

The drilling of hole ER5-4 was completed in March 2001 to a total depth of $1138 \mathrm{~m}$. There are 2 completion zones, with the upper completion zone from 536 to $644 \mathrm{~m}$ and the lower completion zone from 956 to $1021 \mathrm{~m}$. Sampling was performed to acquire chemical data that represent the composite chemistry of all water-producing intervals. The stressed flow logging performed at this well indicated that between 82 and 90 percent of the produced water originated from the upper completion zone. ${ }^{46}$

Samples were collected at ER5-4 on July 5, 2001. Representatives from IT, LLNL and LANL collected samples of the water being pumped from the well. Well sampling and water chemistry data are contained in Table XI. LANL collected two 55-gal. drums, three $2.2 \mathrm{~L}$ pressure tubes and two grab samples. These samples were analyzed for ${ }^{3} \mathrm{H}$, ${ }^{85} \mathrm{Kr},{ }^{237} \mathrm{~Np}$ and gamma activity, as indicated in Table XII.

No activity was found in these samples except background gamma activity in the 55-gal. drum samples. The activity consisted of ${ }^{238} \mathrm{U},{ }^{235} \mathrm{U},{ }^{232} \mathrm{Th}$ and their daughters and ${ }^{40} \mathrm{~K}$.

Even though there was tritium found at $~ 305 \mathrm{~m}$ depth in ER5-4 (in February 2001 ) at an activity level of $\sim 200 \mathrm{~Bq} / \mathrm{L}$, no tritium was detected in these samples above our detection limit of $\sim 30 \mathrm{~Bq} / \mathrm{L}$. 
Table XI. ER5-4 Well Sampling and Water Information

\begin{tabular}{|l|l|}
\hline Volume pumped & $14,000,000 \mathrm{~L}$ \\
\hline Pump Rate & $610 \mathrm{~L} / \mathrm{min}$ \\
\hline Water Temp & $30.2^{\circ} \mathrm{C}$ \\
\hline Electrical Conductivity & $885 \mu$ siemans/cm \\
\hline $\mathrm{pH}$ & 8.7 \\
\hline Dissolved Oxygen & $4.4 \mathrm{mg} / \mathrm{L}$ \\
\hline Turbidity & $0.18 \mathrm{NTU}$ \\
\hline Perforations & 536 to $644 \mathrm{~m}$ \\
& 956 to $1021 \mathrm{~m}$ \\
\hline SWL & $221 \mathrm{~m}$ \\
\hline
\end{tabular}

Table XII. ER5-4 Sample Information and Data (corrected to count time, 09/14/2001)

\begin{tabular}{|l|c|c|c|c|c|c|}
\hline LANL Sample \# & $\begin{array}{c}\text { Collection } \\
\text { Date }\end{array}$ & $\begin{array}{c}\text { Sample } \\
\text { Type }\end{array}$ & $\begin{array}{c}{ }^{3} \mathrm{H} \\
(\mathrm{Bq} / \mathrm{L})\end{array}$ & $\begin{array}{c}{ }^{85} \mathrm{Kr} \\
(\mathrm{Bq} / \mathrm{L})\end{array}$ & $\begin{array}{c}{ }^{237} \mathrm{~Np} \\
(\mathrm{ppq})\end{array}$ & Gammas \\
\hline $4540-01-140$ & $07 / 05 / 2001$ & $\begin{array}{c}55-\mathrm{gal} . \\
\text { drum }\end{array}$ & $<30$ & na & na & $\begin{array}{c}\text { Nat. K, U, Th } \\
\text { and daughters }\end{array}$ \\
\hline $4540-01-150$ & $07 / 05 / 2001$ & $\begin{array}{c}55-\text { gal. } \\
\text { drum }\end{array}$ & $<30$ & na & na & $\begin{array}{c}\text { Nat. K, U, Th } \\
\text { and daughters }\end{array}$ \\
\hline $4540-01-210$ & $07 / 05 / 2001$ & $\begin{array}{c}\text { Pressure } \\
\text { tube }\end{array}$ & $<30$ & LIA & na & na \\
\hline $4540-01-220$ & $07 / 05 / 2001$ & $\begin{array}{c}\text { Pressure } \\
\text { tube }\end{array}$ & $<30$ & $<4 \mathrm{E}-2$ & na & na \\
\hline $4540-01-230$ & $07 / 05 / 2001$ & $\begin{array}{c}\text { Pressure } \\
\text { tube }\end{array}$ & $<30$ & $<4 \mathrm{E}-2$ & na & na \\
\hline $4540-01-160$ & $07 / 05 / 2001$ & $\begin{array}{c}0.25-\mathrm{L} \text { Grab } \\
\text { Sample }\end{array}$ & $<30$ & na & $<20$ & na \\
\hline $4540-01-170$ & $07 / 05 / 2001$ & $\begin{array}{c}0.25-\mathrm{L} \text { Grab } \\
\text { Sample }\end{array}$ & $<30$ & na & $<20$ & na \\
\hline
\end{tabular}

na $=$ not analyzed

LIA $=$ lost in analysis

\section{F. Measurements of ${ }^{237} \mathrm{~Np}$ for Hot Well Samples}

The LANL C-Division Isotope and Nuclear Chemistry group (C-INC) has the ability to detect very small quantities of ${ }^{237} \mathrm{~Np}$ using a stateof-the-art inductively coupled plasma/mass spectrometer (ICP/MS). For the type of samples we analyzed, the detection limit for Np was $\sim 15$ ppq. Samples were taken from the most recently sampled "hot wells" at the NTS. A "hot well" is one in which the radionuclide concentrations in the water, i.e., the hydrologic source term, are large enough to allow for the quantification of 
the radionuclides. The samples were analyzed for ${ }^{237} \mathrm{~Np}$ to determine its activity level in the water samples from various hot wells. The results of the analyses are presented in Table XIII, along with additional sample information.

The tritium activity in each of the samples is included in the table for comparison with the ${ }^{237} \mathrm{~Np}$ values, as well as for inter-sample comparison. All of the ${ }^{237} \mathrm{~Np}$ values are not far above the detection limit and therefore have rather large errors of $\pm 30 \%$ associated with them.

Some of the interesting results from these analyses are as follows:

$1 \quad$ There does not seem to be any correlation between tritium and ${ }^{237} \mathrm{~Np}$ activity. Almendro has the highest tritium but no detectable ${ }^{237} \mathrm{~Np}$, while the wells associated with Cambric have the lowest tritium but relatively higher amounts of ${ }^{237} \mathrm{~Np}$.

2 All of the ${ }^{237} \mathrm{~Np}$ activities from the wells associated with the Cambric test are about the same. This is quite surprising since RNM-1 is located in the test cavity, RNM-2S is $91 \mathrm{~m}$ away and has been pumped extensively, and UE-5n is $560 \mathrm{~m}$ away and has been pumped very little. We assume that the tritium in this well is from water that infiltrated from the RNM-2S ditch, since no ${ }^{85} \mathrm{Kr}$ was detected in the samples.

3 The ${ }^{237} \mathrm{~Np}$ values for the Tybo/Benham holes do seem to make sense. ER20-5\#1 has always had higher activities in all radionuclides than ER20-5\#3, so these results are consistent with the other data we have collected.

Next year we will continue to analyze samples using the ICP/MS. One of the lessons we have learned is that we need to concentrate our samples to increase the ${ }^{237} \mathrm{~Np}$ activities in the analyzed samples and lower the errors associated with them. This year's values, as mentioned before, are close to the detection limit of the instrument and therefore have large uncertainties.

Table XIII. Concentrations of ${ }^{237} \mathrm{~Np}$ in Hot Well Waters Detected by ICP/MS

\begin{tabular}{|c|c|c|c|c|c|c|}
\hline Sample \# & Hole & Name & Collected & $\begin{array}{c}\text { Tritium* } \\
(\mathrm{Bq} / \mathrm{L})\end{array}$ & $\begin{array}{c}{ }^{237} \mathrm{~Np} \\
(\mathrm{ppq})\end{array}$ & $\begin{array}{c}{ }^{237} \mathrm{~Np} * \\
(\mathrm{~Bq} / \mathrm{L})\end{array}$ \\
\hline \hline $4343-01-120$ & UE-5n & Cambric & $4 / 19 / 2001$ & $5.2 \mathrm{E} 03$ & 80 & $2 \mathrm{E}-03$ \\
\hline $4342-00-211$ & RNM-2S & Cambric & $6 / 14 / 2000$ & $7.8 \mathrm{E} 03$ & 80 & $2 \mathrm{E}-03$ \\
\hline $4341-00-211$ & RNM-1 & Cambric & $6 / 28 / 2000$ & $5.9 \mathrm{E} 01$ & 80 & $2 \mathrm{E}-03$ \\
\hline $7910-99-221$ & U-19v & Almendro & $8 / 17 / 1999$ & $5.2 \mathrm{E} 06$ & $<15$ & $4 \mathrm{E}-04$ \\
\hline $8521-99-221$ & U-20n & Cheshire & $10 / 12 / 1999$ & $1.9 \mathrm{E} 06$ & 40 & $1 \mathrm{E}-03$ \\
\hline $0840-98-211$ & U-19q & Camembert & $10 / 20 / 1998$ & $4.4 \mathrm{E} 05$ & 30 & $8 \mathrm{E}-04$ \\
\hline $2051-98-140$ & ER20-5\#1 & Tybo/Benham & $7 / 9 / 1998$ & $2.3 \mathrm{E} 06$ & 210 & $5 \mathrm{E}-03$ \\
\hline $2053-98-110$ & ER20-5\#3 & Tybo/Benham & $4 / 30 / 1998$ & $4.8 \mathrm{E} 03$ & 30 & $8 \mathrm{E}-04$ \\
\hline
\end{tabular}

*Corrected to time of collection 


\section{GROUNDWATER CHARACTERIZATION}

There is a continuing concern on the part of the modelers in the UGTA Project regarding the lack of in situ groundwater chemistry data from wells at the NTS. In August of 2001 LANL, in cooperation with the USGS, employed a Hydrolab Minisonde 4a multiprobe (M-4a) to measure parameters in situ in several uncontaminated wells at the NTS. The probe has the ability to measure the following water parameters: temperature, specific conductivity, dissolved oxygen (DO), $\mathrm{pH}$, and oxidation-reduction potential (ORP). This was the second time the M-4a was used in the field, and the objectives were to further develop procedures to optimize the measurements within the well and to collect additional data to be used by modelers to refine their models.

Eight wells were investigated during this work. The well information is presented in Tables XIV through XXII.

Table XIV. Well and Sampling Information for Wells Measured with the M-4a Multiprobe

\begin{tabular}{|c|c|c|c|c|c|}
\hline Well & $\begin{array}{c}\mathrm{SWL}^{1} \\
(\mathrm{~m})\end{array}$ & $\begin{array}{l}\mathrm{TD}^{2} \\
(\mathrm{~m})\end{array}$ & $\begin{array}{c}\text { Borehole } \\
\text { diam } \\
(\mathrm{cm})\end{array}$ & $\begin{array}{c}\text { CSdiam }^{3} \\
(\mathrm{~cm})\end{array}$ & $\begin{array}{c}\text { Screened } \\
\text { Interval } \\
(\mathrm{m})\end{array}$ \\
\hline ER19-1 & 545 & 1096 & 38.1 & 14.0 & 990-1009 \\
\hline ER20-6\#3 & 615 & 975 & 31.1 & 14.0 & $765-854$ \\
\hline ER6-1 & 472 & 977 & 31.1 & 7.3 & $451-460$ \\
\hline TW-7 & 501 & 693 & 38.1 & 24.4 & $582-686$ \\
\hline UE-20bh1 & 675 & 856 & 34.0 & 31.1 & $\mathrm{Unk}^{4}$ \\
\hline UE4t\#1 & 136 & 735 & 25.1 & 7.3 & $598-607$ \\
\hline UE-4t\#2 & 355 & 735 & 25.1 & 7.3 & $507-525$ \\
\hline WW-2 & 627 & 1043 & 20.0 & 16.8 & $823-899$ \\
\hline
\end{tabular}

${ }^{1}$ Static water level ${ }^{3}$ Completion string diameter

${ }^{2}$ Total depth

${ }^{4}$ Unknown

Table XV. In Situ Water Parameters for ER19-1

\begin{tabular}{|c|c|c|c|c|c|c|c|}
\hline Date & Time & $\begin{array}{c}\text { Depth } \\
\mathrm{m}\end{array}$ & $\begin{array}{c}\text { Temp } \\
{ }^{\circ} \mathrm{C}\end{array}$ & $\begin{array}{c}\text { SpCond } \\
\mathrm{mS} / \mathrm{cm}\end{array}$ & DO\% & $\begin{array}{c}\mathrm{pH} \\
\text { Units }\end{array}$ & $\begin{array}{c}\text { ORP } \\
\mathrm{mV}\end{array}$ \\
\hline \hline $09 / 05 / 2001$ & $15: 20$ & 546 & 26.6 & 0.511 & 1.6 & 10.3 & 259 \\
\hline $09 / 05 / 2001$ & $15: 27$ & 550 & 26.8 & 0.518 & 1.3 & 10.3 & 217 \\
\hline $09 / 05 / 2001$ & $15: 34$ & 565 & 27.0 & 0.554 & 0.9 & 10.4 & 196 \\
\hline $09 / 05 / 2001$ & $15: 41$ & 577 & 27.3 & 0.579 & 0.9 & 10.4 & 184 \\
\hline $09 / 05 / 2001$ & $15: 48$ & 547 & 26.8 & 0.514 & 1.1 & 10.3 & 211 \\
\hline
\end{tabular}

$\mathrm{SWL}=545 \mathrm{~m}$ 
Table XVI. In Situ Water Parameters for ER20-6\#3

\begin{tabular}{|c|c|c|c|c|c|c|c|}
\hline Date & Time & $\begin{array}{c}\text { Depth } \\
\mathrm{m}\end{array}$ & $\begin{array}{c}\text { Temp } \\
{ }^{\circ} \mathrm{C}\end{array}$ & $\begin{array}{c}\text { SpCond } \\
\mathrm{mS} / \mathrm{cm}\end{array}$ & DO\% & $\mathrm{pH}$ & $\begin{array}{c}\text { ORP } \\
\mathrm{mV}\end{array}$ \\
\hline \hline $09 / 05 / 2001$ & $10: 59$ & 621 & 28.5 & 0.410 & 1.6 & 9.0 & 100 \\
\hline $09 / 05 / 2001$ & $11: 06$ & 645 & 29.0 & 0.393 & 1.2 & 9.0 & 62 \\
\hline $09 / 05 / 2001$ & $11: 13$ & 676 & 29.5 & 0.371 & 0.6 & 8.9 & 43 \\
\hline $09 / 05 / 2001$ & $11: 20$ & 706 & 30.0 & 0.352 & 0.4 & 8.7 & 35 \\
\hline $09 / 05 / 2001$ & $11: 27$ & 737 & 30.4 & 0.335 & 0.4 & 8.6 & 35 \\
\hline $09 / 05 / 2001$ & $11: 34$ & 767 & 31.0 & 0.308 & 0.3 & 8.4 & 59 \\
\hline $09 / 05 / 2001$ & $11: 41$ & 721 & 30.3 & 0.344 & 0.9 & 8.7 & 30 \\
\hline $09 / 05 / 2001$ & $11: 48$ & 661 & 29.4 & 0.385 & 1.2 & 9.0 & 52 \\
\hline $09 / 05 / 2001$ & $11: 55$ & 630 & 28.8 & 0.408 & 1.1 & 9.1 & 71 \\
\hline
\end{tabular}

$\mathrm{SWL}=615 \mathrm{~m}$

Table XVII. In Situ Water Parameters for ER6-1

\begin{tabular}{|c|c|c|c|c|c|c|c|}
\hline Date & Time & $\begin{array}{c}\text { Depth } \\
\mathrm{m}\end{array}$ & $\begin{array}{c}\text { Temp } \\
{ }^{\circ} \mathrm{C}\end{array}$ & $\begin{array}{c}\text { SpCond } \\
\mathrm{mS} / \mathrm{cm}\end{array}$ & DO\% & $\mathrm{pH}$ & $\begin{array}{c}\text { ORP } \\
\mathrm{mV}\end{array}$ \\
\hline \hline $09 / 04 / 2001$ & $09: 10$ & 473 & 38.2 & 0.637 & 3.0 & 7.9 & 276 \\
\hline $09 / 04 / 2001$ & $09: 17$ & 473 & 38.2 & 0.637 & 2.4 & 7.9 & 266 \\
\hline $09 / 04 / 2001$ & $09: 24$ & 489 & 38.6 & 0.638 & 2.0 & 7.9 & 143 \\
\hline $09 / 04 / 2001$ & $09: 31$ & 504 & 39.1 & 0.638 & 1.4 & 7.9 & 134 \\
\hline
\end{tabular}

$\mathrm{SWL}=472 \mathrm{~m}$ 
Table XVIII. In Situ Water Parameters for TW-7

\begin{tabular}{|c|c|c|c|c|c|c|c|}
\hline Date & Time & $\begin{array}{c}\text { Depth } \\
\mathrm{m}\end{array}$ & $\begin{array}{c}\text { Temp } \\
{ }^{\circ} \mathrm{C}\end{array}$ & $\begin{array}{c}\text { SpCond } \\
\mathrm{mS} / \mathrm{cm}\end{array}$ & $\begin{array}{c}\mathrm{DO} \% \\
\mathrm{pH}\end{array}$ & $\begin{array}{c}\text { ORP } \\
\mathrm{mV}\end{array}$ \\
\hline $09 / 04 / 2001$ & $11: 00$ & 504 & 22.1 & 0.573 & 6.6 & 8.0 & 206 \\
\hline $09 / 04 / 2001$ & $11: 07$ & 535 & 22.4 & 0.57 & 3.7 & 8.3 & 22 \\
\hline $09 / 04 / 2001$ & $11: 14$ & 565 & 22.7 & 0.557 & 1.7 & 8.4 & -8 \\
\hline $09 / 04 / 2001$ & $11: 21$ & 596 & 23.0 & 0.545 & 1.9 & 8.4 & -20 \\
\hline $09 / 04 / 2001$ & $11: 28$ & 626 & 23.1 & 0.541 & 3.0 & 8.5 & -31 \\
\hline $09 / 04 / 2001$ & $11: 35$ & 657 & 23.1 & 0.541 & 3.3 & 8.6 & -37 \\
\hline $09 / 04 / 2001$ & $11: 42$ & 672 & 23.1 & 0.541 & 3.3 & 8.6 & -43 \\
\hline $09 / 04 / 2001$ & $11: 49$ & 642 & 23.1 & 0.54 & 3.0 & 8.6 & -50 \\
\hline $09 / 04 / 2001$ & $11: 56$ & 626 & 23.1 & 0.542 & 3.6 & 8.7 & -54 \\
\hline $09 / 04 / 2001$ & $12: 03$ & 581 & 22.8 & 0.546 & 3.4 & 8.7 & -59 \\
\hline
\end{tabular}

$\mathrm{SWL}=501 \mathrm{~m}$

Table XIX. In Situ Water Parameters for UE20bh1

\begin{tabular}{|c|c|c|c|c|c|c|c|}
\hline Date & Time & $\begin{array}{c}\text { Depth } \\
\mathrm{m}\end{array}$ & $\begin{array}{c}\text { Temp } \\
{ }^{\circ} \mathrm{C}\end{array}$ & $\begin{array}{c}\text { SpCond } \\
\mathrm{mS} / \mathrm{cm}\end{array}$ & DO\% & $\mathrm{pH}$ & $\begin{array}{c}\text { ORP } \\
\mathrm{mV}\end{array}$ \\
\hline $09 / 05 / 2001$ & $13: 05$ & 681 & 33.9 & 0.1501 & 54.5 & 8.0 & 373 \\
\hline $09 / 05 / 2001$ & $13: 12$ & 696 & 34.2 & 0.1506 & 52.6 & 8.0 & 400 \\
\hline $09 / 05 / 2001$ & $13: 19$ & 711 & 34.4 & 0.1511 & 50.7 & 8.0 & 415 \\
\hline $09 / 05 / 2001$ & $13: 26$ & 726 & 34.8 & 0.1515 & 53.9 & 8.0 & 425 \\
\hline $09 / 05 / 2001$ & $13: 33$ & 742 & 35.3 & 0.1519 & 56.6 & 8.0 & 433 \\
\hline $09 / 05 / 2001$ & $13: 40$ & 757 & 35.8 & 0.1525 & 56.1 & 8.0 & 450 \\
\hline $09 / 05 / 2001$ & $13: 47$ & 772 & 36.4 & 0.1528 & 58.0 & 8.0 & 452 \\
\hline $09 / 05 / 2001$ & $13: 54$ & 726 & 35.0 & 0.1518 & 53.3 & 8.0 & 458 \\
\hline $09 / 05 / 2001$ & $14: 01$ & 696 & 34.3 & 0.1509 & 53.2 & 8.1 & 459 \\
\hline
\end{tabular}

$\mathrm{SWL}=675 \mathrm{~m}$ 
Table XX. In Situ Water Parameters for UE-4t\#1

\begin{tabular}{|c|c|c|c|c|c|c|c|}
\hline Date & Time & $\begin{array}{c}\text { Depth } \\
\mathrm{m}\end{array}$ & $\begin{array}{c}\text { Temp } \\
{ }^{\circ} \mathrm{C}\end{array}$ & $\begin{array}{c}\text { SpCond } \\
\mathrm{mS} / \mathrm{cm}\end{array}$ & DO\% & $\mathrm{pH}$ & $\begin{array}{c}\text { ORP } \\
\mathrm{mV}\end{array}$ \\
\hline $09 / 04 / 2001$ & $13: 33$ & 142 & 18.7 & 0.726 & 1.5 & 8.6 & -183 \\
\hline $09 / 04 / 2001$ & $13: 40$ & 151 & 18.7 & 0.726 & 1.3 & 8.6 & -192 \\
\hline $09 / 04 / 2001$ & $13: 47$ & 167 & 19.1 & 0.726 & 1.0 & 8.6 & -199 \\
\hline $09 / 04 / 2001$ & $13: 54$ & 158 & 18.8 & 0.719 & 2.0 & 8.6 & -154 \\
\hline $09 / 04 / 2001$ & $14: 01$ & 151 & 18.7 & 0.707 & 1.3 & 8.6 & -160 \\
\hline $09 / 04 / 2001$ & $14: 08$ & 148 & 18.6 & 0.699 & 1.9 & 8.6 & -183 \\
\hline $09 / 04 / 2001$ & $14: 15$ & 145 & 18.5 & 0.693 & 1.8 & 8.6 & -187 \\
\hline $09 / 04 / 2001$ & $14: 22$ & 142 & 18.5 & 0.690 & 1.9 & 8.6 & -196 \\
\hline
\end{tabular}

$\mathrm{SWL}=136 \mathrm{~m}$

Table XXI. In Situ Water Parameters for UE-4t\#2

\begin{tabular}{|c|c|c|c|c|c|c|c|}
\hline Date & Time & $\begin{array}{c}\text { Depth } \\
\mathrm{m}\end{array}$ & $\begin{array}{c}\text { Temp } \\
{ }^{\circ} \mathrm{C}\end{array}$ & $\begin{array}{c}\text { SpCond } \\
\mathrm{mS} / \mathrm{cm}\end{array}$ & $\mathrm{DO} \%$ & $\mathrm{pH}$ & $\begin{array}{c}\text { ORP } \\
\mathrm{mV}\end{array}$ \\
\hline $09 / 04 / 2001$ & $14: 42$ & 361 & 23.9 & 1.205 & 1.6 & 10.3 & -281 \\
\hline $09 / 04 / 2001$ & $14: 49$ & 371 & 24.2 & 1.115 & 1.4 & 10.3 & -280 \\
\hline $09 / 04 / 2001$ & $14: 56$ & 386 & 24.5 & 1.116 & 1.6 & 10.3 & -266 \\
\hline $09 / 04 / 2001$ & $15: 03$ & 401 & 25.0 & 1.117 & 1.4 & 10.3 & -258 \\
\hline $09 / 04 / 2001$ & $15: 10$ & 416 & 25.4 & 1.117 & 1.3 & 10.3 & -254 \\
\hline $09 / 04 / 2001$ & $15: 17$ & 422 & 25.6 & 1.116 & 1.9 & 10.3 & -251 \\
\hline $09 / 04 / 2001$ & $15: 24$ & 392 & 24.8 & 1.112 & 1.4 & 10.2 & -138 \\
\hline $09 / 04 / 2001$ & $15: 31$ & 368 & 24.1 & 1.186 & 3.3 & 10.3 & -156 \\
\hline
\end{tabular}

$\mathrm{SWL}=355 \mathrm{~m}$ 
Table XXII. In Situ Water Parameters for WW-2

\begin{tabular}{|c|c|c|c|c|c|c|c|}
\hline Date & Time & $\begin{array}{c}\text { Depth } \\
\mathrm{m}\end{array}$ & $\begin{array}{c}\text { Temp } \\
{ }^{\circ} \mathrm{C}\end{array}$ & $\begin{array}{c}\text { SpCond } \\
\mathrm{mS} / \mathrm{cm}\end{array}$ & DO\% & $\mathrm{pH}$ & $\begin{array}{c}\text { ORP } \\
\mathrm{mV}\end{array}$ \\
\hline $09 / 05 / 2001$ & $08: 35$ & 633 & 27.3 & 0.324 & 1.5 & 7.9 & -97 \\
\hline $09 / 05 / 2001$ & $08: 42$ & 657 & 27.9 & 0.321 & 0.7 & 8.0 & -123 \\
\hline $09 / 05 / 2001$ & $08: 49$ & 688 & 28.5 & 0.319 & 0.5 & 8.2 & -137 \\
\hline $09 / 05 / 2001$ & $08: 56$ & 718 & 29.3 & 0.317 & 0.4 & 8.3 & -143 \\
\hline $09 / 05 / 2001$ & $09: 03$ & 749 & 30.0 & 0.320 & 0.4 & 8.2 & -146 \\
\hline $09 / 05 / 2001$ & $09: 10$ & 733 & 29.7 & 0.317 & 0.3 & 8.4 & -149 \\
\hline $09 / 05 / 2001$ & $09: 17$ & 703 & 28.9 & 0.318 & 0.6 & 8.3 & -148 \\
\hline $09 / 05 / 2001$ & $09: 24$ & 672 & 28.2 & 0.320 & 17.8 & 8.2 & -144 \\
\hline $09 / 05 / 2001$ & $09: 31$ & 642 & 27.5 & 0.323 & 0.7 & 8.1 & -137 \\
\hline
\end{tabular}

$\mathrm{SWL}=627 \mathrm{~m}$

At each site, a laptop computer was used to program the probe to collect data. The time interval between measurements was varied to determine the optimum time interval. The optimum time interval is the shortest amount of time between measurements in which the data parameters can stabilize. For each measurement, the circulator and instruments were given a one minute warm-up.

The probe was connected to the USGS 823 meter etape (an electronic tape measure used in water level measurements). The probe was lowered into the hole, and measurements were taken at specified intervals $(3$ or $6 \mathrm{~m}$ ). After all measurements were completed, the probe was removed from the hole and rinsed with distilled water.

The probe was connected to a laptop computer, and the data were checked to assure that the run had been successful. The data file was transferred from the probe to the computer for assessment. The data from each of the runs are included in the tables.

These data are the first collected with this probe in situ. The probe had been calibrated in the laboratory and used there on samples collected previously. 
A number of observations can be made concerning these data:

1 There are fairly small changes with depth in the holes for $\mathrm{pH}$ and specific conductivity.

2 In several of the wells, WW-2, UE-4t\#1, \#2 and TW-7, the water is reducing.

3 The water in U-20bh1 has consistently higher percentage of dissolved oxygen than the other wells.

This collection of in situ data from these wells demonstrates the capability of the probe to take measurements that are useful to modelers in the UGTA Project. With updated procedures and experience gained from the initial fieldwork, more consistent data will be collected in the future.

\section{PROGRAM SUPPORT ACTIVITIES}

\section{A. Document Reviews/Meetings}

One way in which we support the NNSA/NV mission in Defense Programs and Environmental Restoration is to serve as expert reviewers of documents generated for the UGTA and HRMP Projects. During the past year, we reviewed and edited a number of documents, including the LLNL Frenchman Flat report and the LLNL report titled "Evaluation of the Hydrologic Source Term from Underground Nuclear Tests on Pahute Mesa at the Nevada Test Site: The Cheshire Test."

We helped organize and participated in the RNM Short Course on radionuclide migration presented at NNSA/NV in July 2001. The goal of the course was to present a brief history of the nuclear weapons program at the NTS and the role that HRMP plays in better understanding the effects of the testing on the groundwater. LANL personnel made the following presentations: Radioactivity (Nuclear stability, radioactive decay, nuclear reactions, natural radioactivity) by Joe Thompson, Nuclear Test Phenomenology by Tom Kunkle and Radionuclide Migration Studies at the NTS by Dave Finnegan.

The writing, editing, and updating of the classified and summary NTS Radionuclide Inventory documents consumed a significant amount of time this year. This task was performed in collaboration with LLNL. The reports were last published in 1994, and at that time the summary report, which we intended to publish as an unclassified document, for a number of classification reasons, was not released to the public. However, this classification issue was pursued through the DOE channels, and permission was granted to publish the updated summary radionuclide inventory report. The report was revised and went through an extensive review process and was published at the end of the fiscal year.

The classified report was also revised and is still under review. It should be published in FY 2002. 


\section{B. Presentations/Publications}

D. L. Finnegan and J. L. Thompson, "Laboratory and Field Studies Related to Radionuclide Migration at the Nevada Test Site in Support of the Underground Test Area Program and Hydrologic Resources Management Project, October 1, 1999-September 30, 2000," Los Alamos National Laboratory report LA-13787-PR (January 2001).

S. M. Bowen et al., "Nevada Test Site Radionuclide Inventory, 1951-1992," Los Alamos National Laboratory report LA-13859-MS (September 2001).

We presented a poster showing the results of our FY 2000 work and our proposed work for FY 2001 at the UGTA kickoff meeting. Presentations were also made at the RNM Short Course on radionuclide migration as noted above.

\section{ACKNOWLEDGMENTS}

We are grateful to the many individuals from LLNL, DRI, USGS, IT and BN who provided assistance in collecting water samples and to our coworkers at LANL who contributed to sample analyses. 


\section{REFERENCES}

1. D. C. Hoffman, "Summary of RNM Activities During FY-76 and FY-77 (July 1, 1976 to September 30, 1977)," Los Alamos Scientific Laboratory memorandum CNC-11 to R. W. Newman (November 10, 1977).

2. W. R. Daniels, "Summary of RNM Activities During FY-78 (October 1, 1977 to September 30, 1978)," Los Alamos Scientific Laboratory memorandum CNC-11 to R. W. Newman (November 16, 1978).

3. W. R. Daniels, "Summary of RNM Activities During FY-79 (October 1, 1978 to September 30,1979)," Los Alamos Scientific Laboratory memorandum RNM-CNC-11/11/79-2 to R. W. Newman (November 9, 1979).

4. W. R. Daniels, Ed., "Laboratory and Field Studies Related to the Radionuclide Migration Project, October 1, 1979-September 30, 1980," Los Alamos National Laboratory report LA-8670-PR (February 1981).

5. W. R. Daniels, Ed., "Laboratory and Field Studies Related to the Radionuclide Migration Project, October 1, 1980-September 30, 1981," Los Alamos National Laboratory report LA-9192-PR (February 1982).

6. W. R. Daniels, Ed., "Laboratory and Field Studies Related to the Radionuclide Migration Project, October 1, 1981-September 30, 1982," Los Alamos National Laboratory report LA-9691-PR (May 1983).

7. W. R. Daniels and J. L. Thompson, Comps. and Eds., "Laboratory and Field Studies Related to the Radionuclide Migration Project, October 1, 1982-September 30, 1983," Los Alamos National Laboratory report LA-10121-PR (April 1984).

8. J. L. Thompson, Comp. and Ed., "Laboratory and Field Studies Related to the Radionuclide Migration Project, October 1, 1983-September 30, 1984," Los Alamos National Laboratory report LA-10372-PR (February 1985).

9. J. L. Thompson, Comp. and Ed., "Laboratory and Field Studies Related to the Radionuclide Migration Project, October 1, 1984-September 30, 1985," Los Alamos National Laboratory report LA-10644-PR (January 1986).

10. J. L. Thompson, Comp. and Ed., "Laboratory and Field Studies Related to the Radionuclide Migration Project, October 1, 1985-September 30, 1986," Los Alamos National Laboratory report LA-11081-PR (August 1987).

11. J. L. Thompson, Comp. and Ed., "Laboratory and Field Studies Related to the Radionuclide Migration Project, October 1, 1986-September 30, 1987," Los Alamos National Laboratory report LA-11223-PR (February 1988).

12. J. L. Thompson, Comp. and Ed., "Laboratory and Field Studies Related to the Hydrology/Radionuclide Migration Project, October 1, 1987-September 30, 1988," Los Alamos National Laboratory report LA-11595-PR (July 1989). 
13. J. L. Thompson, Comp. and Ed., "Laboratory and Field Studies Related to the Hydrology/Radionuclide Migration Project, October 1, 1988-September 30, 1989," Los Alamos National Laboratory report LA-11947-PR (November 1990).

14. J. L. Thompson, Comp. and Ed., "Laboratory and Field Studies Related to the Hydrology/Radionuclide Migration Project, October 1, 1989-September 30, 1990,” Los Alamos National Laboratory report LA-12100-PR (May 1991).

15. J. L. Thompson, Comp. and Ed., "Laboratory and Field Studies Related to the Hydrology/Radionuclide Migration Project, October 1, 1990-September 30, 1991," Los Alamos National Laboratory report LA-12338-PR (June 1992 ).

16. J. L. Thompson, Comp. and Ed., "Laboratory and Field Studies Related to the Hydrology/Radionuclide Migration Project, October 1, 1991-September 30, 1992," Los Alamos National Laboratory report LA-12498-PR (January 1993).

17. J. L. Thompson, Comp. and Ed., "Laboratory and Field Studies Related to the Hydrologic Resources Management Program, October 1, 1992-September 30, 1993," Los Alamos National Laboratory report LA-12721-PR (January 1994).

18. J. L. Thompson, Ed., "Laboratory and Field Studies Related to the Hydrologic Resources Management Program, October 1, 1993-September 30, 1994," Los Alamos National Laboratory report LA-12917-PR (March 1995).

19. J. L. Thompson, "Laboratory and Field Studies Related to the Hydrologic Resources Management Program, October 1, 1994-September 30, 1995," Los Alamos National Laboratory report LA-13064-PR (November 1995).

20. J. L. Thompson, "Laboratory and Field Studies Related to the Hydrologic Resources Management Program, October 1, 1995-September 30, 1996," Los Alamos National Laboratory report LA-13270-PR (March 1997).

21. J. L. Thompson, "Laboratory and Field Studies Related to Radionuclide Migration at the Nevada Test Site, October 1, 1996-September 30, 1997," Los Alamos National Laboratory report LA-13419-PR (February 1998).

22. J. L. Thompson, "Laboratory and Field Studies Related to Radionuclide Migration at the Nevada Test Site, October 1, 1997-September 30, 1998," Los Alamos National Laboratory report LA-13576-PR (March 1999).

23. J. L. Thompson, "Laboratory and Field Studies Related to Radionuclide Migration at the Nevada Test Site, October 1, 1998-September 30, 1999," Los Alamos National Laboratory report LA-13701-PR (February 2000).

24. D. L. Finnegan and J. L. Thompson, "Laboratory and Field Studies Related to Radionuclide Migration at the Nevada Test Site in Support of the Underground Test Area Program and Hydrologic Resources Management Project, October 1, 1999-September 30, 2000," Los Alamos National Laboratory report LA-13787-PR (January 2001).

25. D. C. Hoffman, J. R. Stone, and W. W. Dudley, Jr., "Radioactivity in the Underground Environment of the Cambric Nuclear Explosion at the Nevada Test Site,” Los Alamos Scientific Laboratory report LA-6877-MS (July 1977). 
26. J. L. Thompson, Comp. and Ed., "Interim Report of the Drilling History and Analysis for Nevada Test Site Hole UE3e\#4," Los Alamos National Laboratory report LA-UR-12042-MS (December 1990).

27. E. A. Bryant, "Colloid Research at the Nevada Test Site," Los Alamos National Laboratory report LA-12301-MS (May 1992).

28. E. A. Bryant, "The Cambric Migration Experiment-A Summary Report," Los Alamos National Laboratory report LA-12335-MS (September 1992).

29. G. J. Nimz and J. L. Thompson, "Underground Radionuclide Migration at the Nevada Test Site," US Department of Energy/Nevada Field Office report DOE/NV-346 (November 1992).

30. D. K. Smith, B. K. Esser, and J. L. Thompson, "Uncertainties Associated with the Definition of a Hydrologic Source Term for the Nevada Test Site," Lawrence Livermore National Laboratory report UCRL-ID-120322 (May 1995).

31. D. A. Sawyer, J. L. Thompson, and D. K. Smith, "The Cheshire Migration Experiment," Los Alamos National Laboratory report LA-13555-MS (October 1999).

32. D. C. Hoffman, "A Field Study in Radionuclide Migration," in Radioactive Waste in Geologic Storage, S. Fried, Ed., ACS Symposium Series 100 (American Chemical Society, Washington, DC, 1979), p. 149.

33. D. C. Hoffman, W. R. Daniels, K. Wolfsberg, J. L. Thompson, R. S. Rundberg, S. L. Fraser, and K. S. Daniels, "A Review of a Field Study of Radionuclide Migration from an Underground Nuclear Explosion," International Atomic Energy Agency report IAEA-CN-43/469 (1983).

34. D. C. Hoffman and W. R. Daniels, "Assessment of the Potential for Radionuclide Migration from a Nuclear Explosion Cavity," in Groundwater Contamination, Studies in Geochemistry (National Academy Press, Washington, DC, 1984), p. 139.

35. J. L. Thompson and J. S. Gilmore, "Migration of Fission Products at the Nevada Test Site: Detection with an Isotopic Tracer," Radiochim. Acta 52/53 229 (1991).

36. J. L. Thompson, "Radionuclide Migration Studies at the Nevada Test Site," Radiochim. Acta 54, 149 (1991).

37. J. L. Thompson, "Studies of Fission Product Movement in Tuffaceous Media," Radiochim. Acta 58/59 273-276 (1992).

38. M. Mathews, K. Hahn, J. Thompson, L. Gadeken, and W. Madigan, "Dalhart Post Shot Investigation," in Proceedings of the Fourth International Symposium of the Minerals and Geotechnical Logging Society, Toronto, Canada, August, 1991; published by the Society of Professional Well Log Analysts, 6001 Gulf Freeway, Houston, TX 77023 (1993). 
39. W. L. Hawkins, D. A. Trudeau, and S. L. Drellack, Jr., "Hydrogeologic Investigations at the Nevada Test Site," in Proceedings of Industrial and Agricultural Impacts on the Hydrogeologic Environment, Second USA/CIS Joint Conference on Environmental Hydrology and Hydrogeology: American Institute of Hydrology, May 17-20, 1993; Washington, DC, pp. 87-104.

40. J. L. Thompson, "Fission Product Distribution in Nuclear Test Cavities/Chimneys," in Proceedings of the Fourth Annual International Conference on High Level Radioactive Waste Management, Vol. 2, p. 1517, April 26-30, 1993, Las Vegas, NV (published by the American Nuclear Society and the American Society of Civil Engineers).

41. J. L. Thompson, "The Nevada Test Site: An Analog for a Nuclear Repository," in Proceedings of the Fourth International Conference on the Chemistry and Migration Behavior of Actinides and Fission Products in the Geosphere, p. 579, December 12-17, 1993, Charleston, SC (published by R. Oldenbourge Verlag, Munchen, 1994).

42. M. Mathews, K. Hahn, J. Thompson, L. Gadenken, and W. Madigan, "Subsurface Radionuclide Investigation of a Nuclear Test," J. Appl. Geophysics 32 279-291 (1994).

43. A. B. Kersting, et al., "Migration of Plutonium in Ground Water at the Nevada Test Site," Nature 397 56-59 (1999).

44. R. W. Buddemeier and D. Isherwood, "Radionuclide Migration Project 1984 Progress Report," Lawrence Livermore National Laboratory report UCRL-53628 (April 1985).

45. International Technologies, "Frenchman Flat Well Cluster ER5-3 Data Report for Development and Hydrologic Testing," IT preliminary report (September 2001).

46. International Technologies, "Frenchman Flat Well Cluster ER5-4 Data Report for Development and Hydrologic Testing," IT preliminary report (September 2001). 

This report has been reproduced directly from the best available copy. It is available electronically on the Web (http://www.doe.gov/bridge).

Copies are available for sale to U.S. Department of Energy employees and contractors from-

Office of Scientific and Technical Information

P.O. Box 62

Oak Ridge, TN 37831

(865) 576-8401

Copies are available for sale to the public from-

National Technical Information Service

U.S. Department of Commerce

5285 Port Royal Road

Springfield, VA 22616

(800) 553-6847 


\section{$\overbrace{\text { LATIONAL LAB ORATORY }}$}

Los Alamos NM 87545 